accepted by IJCV on June 8th, 2020

Identity, Significance, Sensation or Justice?

Different Motivations for Being Attracted to Radical Ideas

\author{
Julia Reiter* \& Bertjan Doosje** \\ * University of Vienna \\ ** University of Amsterdam
}

\begin{abstract}
Author note
Other parts of the data sets described in the present manuscript are analysed in a separate article, currently under review. We extend our deepest gratitude to Nadine Jukschat and her colleagues at the Criminological Research Institute of Lower Saxony (KfN e.V.) for conducting part of these interviews and providing us with the transcripts.
\end{abstract}

Correspondence concerning this article should be addressed to Bertjan Doosje, Department of Psychology, University of Amsterdam, Nieuwe Achtergracht 129B, 1018 WS Amsterdam, the Netherlands. Tel: (+31) (0)20 - 52568 85. E-mail: E.J.Doosje@uva.nl.

Requests regarding study materials or data should be addressed to Julia Reiter, Department of Educational and Developmental Psychology, University of Vienna, Universitätsstr. 7, 1090 Vienna, Austria. E-mail: reiterj94@univie.ac.at 


\begin{abstract}
People have different motivations for feeling attracted to radical ideas. In the present study, we propose four such motivations, resulting in four types: the identity seeker, the significance seeker, the sensation seeker, and the justice seeker. To test this model, we conducted five narrative interviews with individuals who had disengaged during the early stages of radicalization (Study 1) and seven semi-structured expert interviews with employees of German deradicalization programmes (Study 2). Data were analysed using Thematic Analysis (Braun and Clarke 2006). In sum, the proposed typology could not be fully supported, but the individual motivations making up the types were all reflected in the data, the most important being the need to belong, personal uncertainty, and need for status. The key finding of this study is that, rather than generalise over types of radicalization or types of ideologies, it is beneficial to analyse individuals according to their personal combination of psychological needs and their saliency. We relate this to past research and discuss practical implications.
\end{abstract}




\section{Identity, Significance, Sensation or Justice? \\ Different Motivations for Being Attracted to Radical Ideas}

All models of the radicalization process currently in use recognize some variation of factors - such as risk factors and trigger factors - furthering and shaping the course of the process. Individual susceptibility to these factors varies; we argue that this susceptibility is modulated by personal motivational tendencies. Individual motives in the radicalization process have been discussed by various authors, but a comprehensive motivational typology had not been put forth until Macdougall et al. presented theirs in 2018. We utilize the motivational typology presented by Macdougall et al., which they derived from a review of the current literature, include it in our own comprehensive model which combines motives and risk- and trigger factors, and present the first empirical test of such a comprehensive motivational typology using a set of qualitative data from two small-scale interview studies. In Study 1, we analyse interviews conducted with people who had displayed a certain vulnerability to and exploration of radical ideologies. In Study 2, we examine data we gathered by conducting semi-structured interviews with seven experts on the (de-)radicalization process. Thus, the present article extends the current state of research in several ways: Firstly, our model is the first to systematically unify motivational types, risk factors and trigger factors in one comprehensive model, allowing us to make limited observations on how they may have a combined effect. Secondly, we applied the same theoretical model to data sets from different groups in Study 1 and Study 2, which enables us to add to the state of research by making a direct comparison between first-hand and second-hand perspectives on the radicalization process. This information is valuable for interpreting results of previous research which used second-hand data, such as expert interviews. Finally, 
we put Macdougall et al.'s (2018) four motivational types, which were developed experimentally, to the test using field data for the first time.

\subsection{Radicalization: term and process}

Our analyses of psychological needs and motives or radicalization are part of a larger study (Reiter 2018) in which we examined a four-plus-one stage model of (de-)radicalization, wherein we conceptualized radicalization as the process of accepting violence as a justified means of achieving certain political goals (Doosje et al. 2016). The phases of radicalization, derived from current literature (mainly drawing on Doosje et al. 2016 and Feddes, Nickolson, and Doosje 2018) and further analyses of our data, are vulnerability, exploration, membership, and finally, action. Deradicalization or disengagement (the former concerning beliefs and attitudes while the latter refers to behaviour; cf. Altier, Thoroughgood, and Horgan 2014, Dechesne 2011, Della Porta and LaFree 2012, Demant et al. 2008, Veldhuis 2012) can occur during any of these phases, implying that the process is not necessarily linear. The development of a radical belief system has been linked to the occurrence of violence: in two large-scale surveys, Doosje and colleagues (Doosje et al. 2012, Doosje, Loseman, and Van den Bos 2013) successfully used the components of a radical belief system to predict both attitudes towards violence by other in-group members and own violent intentions.

\subsection{Motivational typology}

Different motivational structures - that is, different psychological needs - can modulate responses to radicalizing stimuli even in the presence of the same vulnerability factors (e.g. Cottee and Hayward 2011, Demant et al. 2008, Macdougall et al. 2018). These needs are relatively fixed predispositions to certain behaviours, perceptions, reactions, and differential motivational responses to stimuli. Existing typologies frequently highlight one aspect at the expense of others, which results in overly sim- 
plistic or one-sided models. By contrast, Macdougall et al. (2018) present a comprehensive model unifying different angles of existing literature, resulting in four types: the identity seeker, the significance seeker, the sensation seeker, and the justice seeker. Each of these types consists of discrete psychological constructs, which Macdougall et al. measured using questionnaires and which we adapt to be applicable to qualitative data. Since Macdougall et al. were able to prove with experimental data that the types which they synthesized based on previous literature on the subject are all, to varying degrees, relevant to the process of radicalization, we build our studies on their model.

The identity seeker type encompasses motivations concerning the person and their role in society - the need to know who they are, where and with whom they belong. It is described by Bjørgo (2011), Choudhury (2007), Hogg (2014), King and Taylor (2011) - who also relate identity-related issues to experiences of discrimination - and Venhaus (2010), amongst others. A strong motivation of this kind causes heightened susceptibility to peer pressure and is, as such, the mark of the typical follower. Identity motives are not only most frequently represented in theory (though perhaps on par with the significance seeker type), but there is also evidence that they are empirically the largest group: Venhaus (2010) defines four seeker types - identity, revenge, status, and thrill - and, in an analysis of $\mathrm{N}=2032$ case files and interviews of former Al Qaeda recruits and other radical Islamists, concludes that identity seekers are the largest group (40\%). We operationalize identity seeking through the psychological constructs need to belong and a disposition for personal uncertainty (entailing the need for uncertainty avoidance). Need to belong represents a strong motivation by social belonging, causing behaviours aimed at integrating into a group and avoiding isolation. People with a strong need to belong are highly sensitive to social exclusion and emotionally dependent on being accepted by others. Personal uncertainty - dubbed emotional uncertainty by Macdougall et al. because an emotional measure was used, unlike in our 
interviews - describes feelings of uncertainty and insecurity concerning different aspects of one's life and world view, resulting in seeking out clear rules, strong structures and black-and-white ideologies, because they offer uncertainty reduction and increase security. People with high personal uncertainty tend to be rigid, anxious when confronted with sudden changes, and cope poorly with uncertain situations.

The significance seeker type describes anyone with a strong desire for significance, be it personal significance - a desire for high personal status - or existential significance - a desire for definitive answers to life's existential questions. This type appears in most typologies, albeit under different names. Cottee and Hayward (2011) identify three "existential motivations": the desire for excitement, the desire for ultimate meaning and the desire for glory, the latter two of which are identical to the components of significance seeking. The significance-motive has also been central to Kruglanski and colleagues; Dugas and Kruglanski (2014) propose the "Quest for Significance Model", in which a desire for personal significance and glory is the central driving force behind radicalization. The differentiation between need for improvement of status and self-image (Doosje et al. 2016, Dugas and Kruglanski 2014, Venhaus 2010, Webber and Kruglanski 2018) and for transcendent existential meaning (Kruglanski et al. 2009) is also upheld in many of his other works. This type is thus a compound of the constructs need for existential meaning and need for status, which motivate an attraction to ideological systems and figures offering a clear world view and a set of rules and behaviours aimed at increasing one's social status, public image and self-worth based on the opinions of others.

A less commonly represented type is the sensation seeker. It is marked by a need for excitement (e.g. Bakker and De Leede 2015, Bjørgo 2011, Cottee and Hayward 2011, Venhaus 2010) and a need for romance (e.g. Bakker and De Leede 2015, Gellin 2015, Hoyle, Bradford, and Frenett 2015). The former is the classic sensation 
seeking, resulting in seeking out risky behaviors producing a characteristic adrenaline rush, sometimes including dangerous and illegal activities, while the latter describes a desire for short-term romantic entanglement, characterized not by serious emotional connection but by the excitement of newness and potential promiscuity. This is distinct from a desire for serious long-term emotional connection to a romantic partner, which is a possible iteration of the need to belong.

Finally, the justice seeker type is based on the concept of justice-seeking as a general factor of radicalization as described by, for example, Borum (2003) and Van den Bos (2018). Inter-individual differences in sensitivity to violations of fairness have been found in various studies (e.g. Gollwitzer et al. 2009). Need for justice describes a heightened sensitivity to injustice as well as a strong tendency to be motivated by the pursuit of justice, to react strongly and emotionally to unfair treatment, and to engage in behaviours aimed at restoring justice (according to the individual's own definition).

We examined whether and to which extent the psychological needs underlying this typology would be represented in our qualitative data. Aside from substituting personal for emotional uncertainty, as described above, we applied Macdougall et al.'s motivational model as intended by the authors. We hypothesized, based on our literature analysis, that the identity- and significance-seeker types would be represented more strongly than the other two types.

\section{Method}

We conducted two qualitative studies: In Study 1, we analysed data collected from interviewees in the initial phases of our process model (vulnerability and exploration). In Study 2, we analysed data collected from expert-interviews with consultants 
employed in different German exit-programmes (i.e. programmes which support members of radical groups who are willing to disengage). Approval was granted by the ethics commission of the University of Göttingen.

\subsection{Study 1}

\subsubsection{Sample}

Five anonymized interview transcripts were provided for secondary analysis by the Criminological Research Institute of Lower Saxony. These were narrative interviews conducted with Muslims who displayed a certain vulnerability to and exploration of radical ideologies, but did not move on to the membership- or action phase. Participants were recruited via Facebook and Instagram, based on self-identification as a devout Muslim. They self-selected by contacting a profile set up especially for the study upon seeing an advertisement for participants. The narrative interview is a method (Schütze 1976) in which the interviewees are presented with a general narrative prompt and then allowed to unfold their own narrative, choosing their own topics to focus on, while remaining uninterrupted by the interviewer except for clarifications. Our data set was selected from the total data corpus of twelve interviews by the interviewer, with the criterion that the participants should have had some contact with radical groups (see Table 1).

\subsubsection{Interview}

At the beginning of the interview participants were asked to talk about their religious development, what had led to their self-identification as devout Muslims, and which influences they considered important on this journey. The interviewees talked freely, without interruption except for clarification or elaboration on certain aspects, so as not to cut the narrative short or divert the focus of the interview from the one chosen by the interviewees. 


\subsubsection{Analysis}

The procedure used was thematic analysis as defined by Braun and Clarke (2006). A theoretical approach was taken to the procedure's six steps: An original set of codes was developed within a theoretical framework prior to the first analysis of the data and subsequently built on inductively.

In step 1, two interviews were chosen randomly for initial reading. In a second step, codes were created based on previously researched literature. They were then applied to one of these initial interviews as well as a newly selected third one. During this step, other recurring topics were identified as relevant to the research questions and added as codes. The resulting final coding scheme was then applied to the entire data set. After all data were coded, the codes were collated into meaningful themes, partly guided by the theoretical framework and partly by the way the data were interpreted as context. The themes were then, according to steps 4 and 5 of the analysis, reviewed, defined and named.

Coding system. The coding system included the seven psychological constructs underlying our proposed motivational typology (as described above) and various other codes which are not pertinent to the present article (but see Reiter 2018). The overall coding system (Appendix 1) was adapted in an iterative process, but the codes concerning the typology were not affected by this.

The minimal coding unit chosen was a sentence. However, if the same topic was expressed in more than one sentence without interruption by another topic, the entire coherent segment was marked with the corresponding code once, rather than every sentence individually.

Reliability/inter-rater agreement. After all interviews had been coded by Coder $\mathrm{A}$ (the interviewer), Coder $\mathrm{B}$ received coding training by Coder $\mathrm{A}$ and then coded an interview. The training involved a comprehensive instructional document and an 
additional question- and answer- session. Basic coding rules included that it was possible and sometimes necessary to apply multiple codes to the same data item, that codes were meant to be applied generously (i.e. including the context if necessary), and that most codes could be applied both in the positive and negative sense (i.e. to mark the presence or explicit absence or opposite of the code). The total number of codes used by Coder A was revealed to Coder B as a guideline.

As there were five interviews (10.9 hours total), the interview chosen for doublecoding by a random number generator ( $\mathrm{Nr} .1 .4,2.43$ hours) made up $22.29 \%$ of the data set. After Coder B had finished coding this interview, the initial amount of interrater agreement was established. Agreement was defined as any instance of the same code being applied by both coders to a coherent segment. However, the structure of the data and the way they were coded were not fit for the calculation of standard reliability indices (as listed in Zhao, Liu, and Deng 2016) and consequently, no statements can be made about true inter-rater reliability. Calculation of any reliability index requires data to be pre-divided into a fixed number of units, resulting in a number of data units on which raters agreed and disagreed, respectively. However, in our study, raters created the data units while coding. Thus, the data to which no codes were applied remained undivided into units - thus, we can name count the units on which the raters agreed, but not those on which they disagreed. Consequently, our evaluation of interrater agreement is limited to the percentage of overlap.

Coders $A$ and $B$ then discussed all instances of disagreement together in order to determine the cause of the disagreement and whether it could be resolved. Coder B was instructed beforehand that for each instance of disagreement, the possible outcomes were resolution in favour of Coder A, resolution in favour of Coder B, or non-resolution of the disagreement. The level of inter-rater agreement was then re-assessed. 
Table 2 presents the resulting overlap before and after discussion. As demonstrated by the considerable improvement in inter-coder overlap post discussion, most conflicts could be resolved; they were found to be mostly due to simple lapses of concentration caused by the large number of codes or by uncertainty resulting from the occasional vagueness of the interview material. On several instances, the coders could agree on what would fall under the code's definition but could not agree on whether this was clearly enough implied in the data.

\subsection{Study 2}

\subsubsection{Sample}

For the second part of the study semi-structured interviews were conducted with seven experts on the (de-)radicalization process. The target group were consultants at German state- or privately-run exit-programmes ( $n=6$ and $n=1$, respectively), i.e. professionals who work directly with radicalized individuals seeking help to leave their radical group (see Table 3). All programmes pursue the same basic intervention approach (targeting disengagement before deradicalization by first helping the client to change their circumstances, e.g. move, find a new job, build a new social circle, and then starting to work on the mindset). Naturally the state-run programmes are more well-equipped to give practical life support to their clients (e.g. by vouching for their clients when renting a new apartment or starting a new job). Participants were recruited via e-mail: First, we compiled a list of suitable programmes that was, to our knowledge, complete. The people behind these programmes were subsequently all contacted to ask for their collaboration. Interviews were conducted with everyone who responded to these messages. The interviews were conducted face-to-face at the participants' offices during June 2018, recorded and later transcribed. 
Experts on various ideological backgrounds were interviewed, because we argue that political and religious radicalization are not fundamentally different. Similarities between religious and political radicalization have been found in terms of risk factors (Doosje et al. 2012, Doosje, Loseman, and Van den Bos 2013, Schils and Verhage 2017), individual motivations (Webber and Kruglanski 2018) and factors leading to disengagement and deradicalization (Barrelle 2014, Harris, Gringart, and Drake 2017, Webber and Kruglanski 2018). The minor differences that did occur between ideologies are discussed below.

\subsubsection{Interview}

Guiding questions (Appendix 2) for the semi-structured interviews were developed on the basis of the theoretical background and the findings from the data analysis in Study 1. The interview consisted of an introductory part (own professional background, daily routines at work), a part about radicalization, another about deradicalization (during both: recognition of different types, examples), and a final concluding part, which was a slot for the interviewees to provide concluding remarks, add information or ask questions.

\subsubsection{Analysis}

The interviews were transcribed using the software f4transkript according to standard transcription rules (Fuß and Karbach 2014) and checked against the original sound recordings for accuracy. The methods of analysis and coding procedure were analogous to those used in Study 1. The order in which the interviews were coded was determined by a random number generator. As there were seven interviews $(9,60$ hours total), the interview chosen for double-coding by a random number generator (Nr. 2.4, 1,55 hours) made up 16,15\% of the data set. Table 4 presents the resulting overlap in percent before and after discussion. The dramatic rise in agreement after discussion paralleled that in Study 1. 
Finally, the interviewees from Study 2 were provided with a draft of the analyses and given an opportunity to respond and request corrections (which none of them seized); they had also, upon request, been provided with their own interview transcripts.

\section{Results}

We hypothesized that the psychological needs making up the four seekertypes introduced above would all be reflected in the data. Additionally, we hypothesized that evidence of identity- and significance-seeking would appear more frequently than the other two types. Figure 1 illustrates the frequency of all seven needs related to the four seeker types in both studies.

\subsection{Need to belong and emotional uncertainty - identity seeker type}

Need to belong was reported most frequently in both studies. The need for social belonging was considered a key factor by all experts, particularly so for right-wing extremists (e.g. 2.2: "Conditions [at home] are often precarious, (...) and the children who are socialised like this don't develop high self-esteem, and then they search for people they can hold on to, for group membership - they are accepted well in those groups, they are treated well, and in the end that is what causes this strong connection to the right-wing scene.") Need to belong also was reported to be one of the most important factors in deradicalization, at least for right-wing extremists: “(...) What brings us rather a lot of people wanting to de-radicalize is the beginning of a new relationship. So that is another very important factor, someone starting a relationship with someone outside the scene (...)" (2.7).

Personal uncertainty was the runner-up in both studies. A frequently mentioned aspect thereof was uncertainty avoidance, a longing for clear and strict rules, for example 1.3: “(...) [in Islam] there's an answer to everything. Christianity doesn't have that, no other religion has that" as well as for structure in general (e.g. 2.2: "(...) with a 
pure follower-type, it's very important to give him stability, and to replace the group by that - that works very well"). Another aspect was that of finding one's identity; for example, interviewee 2.3 described a strong need for affirming one's gender identity as a way to combat feelings of uncertainty in life: "There's something very martial about the right-wing extremist scene, especially for the men, there's a huge obsession with masculinity, everyone needs to have big arms and so on. And for women, too, there are clear roles. And that offers a lot of security." Notably, the construct of gender identity is highly complex and could thus touch upon various psychological needs described in our typology. However, in the context of this interviewee's quote, we argue it is most strongly linked to identity-related personal uncertainty; seeking to consolidate one's identity by investing in one's association with a social group, as one does by putting effort into performing gender, is in keeping with the principles of Social Identity Theory (Tajfel and Turner 1979, Tajfel and Turner 1986).

There is some evidence in the data to support a coherent identity seeker type. Specifically, the interviewees in Study 2 produced various typologies, but identity seeking appeared to be a constant (circumscribed as "the classical follower" (2.2), referencing a distinction suggested by, e.g., Bjørgo 2011, or "secondary radicalization" (2.3, 2.6), leaning on a distinction between radicalization due to ideological conviction and ideology used as a mere justified re-interpretation of a pre-existing criminal career, e.g. Bock 2017). Interviewee 2.7 describes the intersection of need to belong and need for personal security as the key element in his work: "This has really been, throughout these seventeen and a half years, the central, recurrent theme in all de-radicalized clients' biographies. It is very noticeable that, in most cases, a father figure was nonexistent, and therefore they sought this father figure among older comrades, older likeminded people, just anyone who would take their hand and give them a feeling of se- 
curity and [say] 'I'll give your life direction'. That is the mark of all de-radicalized biographies." And interviewee 2.1 explicitly states: "The identity-type is certainly the largest portion. I think that's psychologically also due to puberty, who am I, where am I from. For example, I have a Turkish background, I'm perceived as a Turkish person, but maybe I don't even speak the Turkish language and I try to define myself via religion, to find my identity. (...)"

3.2. Need for existential meaning and need for status - significance seeker type

Need for existential meaning overlapped, to some extent, with personal uncertainty in that providing clear and simple answers to complex questions appeals to both these needs. The need for existential meaning, for purpose and answers to fundamental questions was more prevalent in Study 1 than in Study 2, suggesting this motive might be more central in religious than in right-wing political radicalization - e.g. 1.3: "Why am I alive, what is the meaning of my life? Christianity doesn't provide an answer to that. Why did God create man? Yes, he wanted an image of himself, but why, Christianity doesn't provide an answer to that." This difference might also be related to the different data sources. Need for existential meaning is a profoundly personal, fundamental and potentially spiritual need, which interviewees talking from a first-person point of view on radicalization might be more likely to identify and describe than experts working with radicalized people, whose work tends to focus on hands-on support in rebuilding a life after radicalization. Moreover, there could be a tendency to over-report this motive in self-report, as it is more flattering and socially desirable than admitting to a simple need to belong somewhere or increase one's social status. Some interviewees in Study 2, leaning on the concept of primary and secondary radicalization explained above, theorized that perhaps these people do exist among right-wing and other radicals as well, but are less likely to seek a deradicalization-programme's help 
(e.g. 2.3: "We do get those, the ideologists (...) but the majority is different."), stating that their motivation is more earnest and their disengagement therefore less likely. The interviewees also stressed that the question of purpose needs to be considered when providing support to someone's deradicalization process.

Need for status was an important motive in both studies and included instances of wanting to feel important, perhaps powerful, seeking out behaviours that increase one's social value - for example 1.4: "[talking about a radical group] for me they were, whenever I saw them on the internet, they were stars, like celebrities. Then I really saw them in [city] and told them 'I want to join you'." This can include a quest for dominance (e.g. 2.1: "What I notice over and over again, and that's not necessarily independent from a quest for identity, is a quest for power. (...) This quest for power in the sense of 'I want to be looked up to and to be the one in charge', that is, I think, a very important motivator - not for all of our clients, but for some. Especially those with narcissistic personality structures"). Need for status is also closely tied in with self-image (e.g. 2.3: "(...) many say that in the beginning, they were just tagging along, and then during the first crimes that are being committed, one just gets carried away, and you feel very powerful, you think 'wow, awesome, I'm a total hero now'”). Consequently, self-esteem and self-efficacy beliefs are the key reasons for a resource-oriented approach to deradicalization work.

In summary, need for existential meaning and need for status can be connected, but, as demonstrated by the large difference in frequency in Study 2, that is certainly not always the case. Need for status is described as the more essential and prevalent motivation between the two. There could be a social desirability bias at play here, i.e. people might be less likely to admit to being motivated by a need for status than they would be to identify this motivation in someone else. Connections of the two with other 
motivational needs are also described. Overall, the two needs are not connected strongly and exclusively enough to speak of a coherent significance seeker type.

3.3. Need for romance, need for sensation and need for justice - sensation seeker and justice seeker type

The needs for romance and sensation each played a minor role in Study 1. One interviewee (1.4) mentioned that in learning more about Islam, he was hoping to become more appealing to Muslim girls. Another interviewee explained that young girls are sometimes tricked into radical groups by promises of a romantic, better life in a new country (1.1). She also explained that she briefly wore a niqab, because it was adventurous to see how people would react to her on the streets. Overall, the results from Study 1 are not in line with a coherent sensation seeker type.

The results of Study 2 differed in that need for sensation was more frequent, although frequency alone is not an accurate depiction of the factor's importance here. When asked about the importance of need for sensation in the right-wing extremist scene, interviewee 2.7 explained it is merely secondary to, and therefore usually coupled with, a need to belong or need for status: "If I want to go on an adventure alone, if I do something crazy alone, I haven't gained any status with others with that. Okay, in the age of Social Media, I can post on Instagram about putting up some crazy posters on a church tower by myself, or something, like the 'Identitären' [a contemporary right-wing group], but even they do it as a group activity, because (...) in a community, you're stronger, that is true for both extremists and democratically minded people." This is in line with other interviewees' descriptions: while need for sensation plays a role in keeping people in the right-wing scene in the sense that entertainment is provided (alcohol, concerts, and occasionally violent confrontations with the police - all of which creates positive emotional ties to the group) and in motivating members of the Islamist scene to take the final step and emigrate (e.g. to Syria), it does not generally 
seem to be a factor that can stand on its own as a motivation. The same seems to be the case for need for romance, which interestingly was only mentioned by the two interviewees working with Islamists (three times overall). Again, the results are not in line with the assumption of a coherent sensation seeker type.

While need for justice was not mentioned at all in Study 1, in Study 2 it was mentioned 24 times - but again, frequency does not tell the whole story. Some sorted a strong need for justice into the type of the "primarily radicalised" (together with need for existential meaning, as described above; e.g. 2.1 [asked about those clients who had left for Syria]: "It was simply -, the ideological conviction 'I have to help them and I have to restore justice' was simply stronger (...)"), while others did not see it as a genuine, legitimate need so much as an excuse, a strategy for justifying involvement in the radical group and generally criminal behaviour (2.5: "I'd be careful about need for justice, because sure, that's often what it looks like from the outside, all that 'us against the others' and 'they're so well off and we're doing so poorly', but I think sometimes that's just a strategy, an argumentative strategy being used"). Interviewee 2.2 theorized that where the need for justice is genuine and strong, deradicalization becomes unlikely. Need for justice is also frequently appealed to by propaganda seeking to create a perception of injustice. The concept of the justice seeker as an independent type does not appear to be a good reflection of these results.

\subsection{Interrelations}

We explored possible interrelations between phases of our process model and psychological needs. It must be noted that our capacity to observe such interrelations was limited, partly due to the differences in our samples. Bearing this in mind, we observed a pattern in the above descriptions, which is that for those who were originally attracted to the radical group by their need to belong, emotional uncertainty and/or 
need for status, need for justice becomes relevant around the transition from membership to action phase. The longer someone is a member of a radical group, the more the group indoctrinates them regarding ideology and perceived injustices against the in-group, and eventually the individual begins to justify their behaviour in the name of justice.

\section{Discussion}

In the present article, we examined seven psychological needs motivating (de-)radicalization and their relations amongst each other. To this end, we conducted a twopart interview study utilizing different data sources. We hypothesized that our qualitative data would contain information on the factors need to belong, personal uncertainty, need for existential meaning, need for status, need for sensation, need for romance, and need for justice, as proposed by Macdougall et al. in their model; further, we expected that amongst these, the identity seeker (need to belong and personal uncertainty) and the significance seeker (need for existential meaning and need for status) would be the most frequently reported.

As expected, all seven needs were represented in the data, and indeed, those related to identity-issues and social belonging were most frequently reported. However, contrary to our expectations, there was too much overlap for a clearly demarcated typology to hold up; not only did most interviewees show several needs rather than one prominent need, but the concept of personal uncertainty overlapped with need to belong regarding identity issues as well as with need for existential meaning regarding a desire for definitive answers and guidance at roughly the same frequency. Additionally, taking into account the results of Study 2 , there are likely two broad main types, comprised of the need to belong and personal uncertainty on the one hand and personal uncertainty and need for status on the other hand, while the other needs (for sensation, for romance and for justice) may play a role for either of these types at 
different stages of the process. If one were to draw this distinction, our psychological needs could be related to the dual model of leaders and followers as presented by Bjørgo (2011), with the need to belong in combination with personal uncertainty roughly relating to the follower-type and the need for status corresponding to the leader-type. Ultimately, it is more useful to acknowledge the importance of each of these motives for what it is than to try and force these motives into coherent types.

Overall, the importance of these motives in our data is in line with previous radicalization literature which has highlighted the central role of uncertainty and the quest for significance and definition as a motivator (e.g. Van den Bos 2018, Dugas and Kruglanski 2014), as well as with early findings on the need to belong as a central motive in human behaviour (e.g. Baumeister et al. 2007, Baumeister and Leary 1995). The frequent coincidence of need to belong and personal uncertainty, indicative of people's attempts to gain security and define their identity by association with a social group, is also in keeping with Social Identity Theory (cf. Tajfel and Turner 1979, Tajfel and Turner 1986); associating oneself strongly with a social group can reduce uncertainty in different ways. Uncertainty about one's day-to-day life, about what to think about certain things, what to do and how to act, can be reduced by aligning oneself with a social group that prescribes a coherent set of rules. Similarly, uncertainty about one's own identity and values can be reduced by making membership in a social group a central part of one's identity, as the group will typically provide some rules as to what it is and is not. However, social belonging is a basic human need that goes beyond uncertainty reduction and identity construction; that is to say, while in some people need to belong and personal uncertainty do overlap and they seek group membership as a way to define themselves and give themselves structure and rules, others who also report need to belong as a motive join radical groups because they are simply 
lonely. This is why it is important to acknowledge these psychological motives individually.

Regarding personal uncertainty and need for status, it is important to highlight the multiple facets tied into need for status. In both studies, the word "power" was frequently used and the concept of power seeking was highlighted as a central motive. Of course, power and status are not identical; power is the ability to achieve and control certain things, to successfully pursue one's interests and exert social dominance. Status can be seen as both a source and a derivate of power: Having real power in some area of life will boost an individual's status in their peer group, but at the same time, having a certain status in a peer group will give an individual a spot in that group's hierarchy and give them power over those beneath them. What transpired in our interviews was that, while the actual power achieved in a radical group may often be limited, it is the subjective feeling of power that people with a strong need for status motive seek. These are often people in an otherwise low social position, unsuccessful in education or career and aware or convinced of their lack of opportunity to change this; living under such conditions can negatively impact self-efficacy beliefs and, more generally, self-esteem. However, these deficits can be compensated by achieving power, status and agency in some other area of life. In short: When someone finds themselves in a low societal position due to frequent experiences of failure and perceives themselves to be unable to change this, they may turn to the limited social hierarchy of a new ingroup, such as a radical group, within which they find themselves able to improve their social status through actions.

A possible third main type derived from the expert interviews is that described as "the ideologist" or "the primarily radicalised" - a type unifying need for existential meaning and need for justice, marked by strong and primary commitment to the ideol- 
ogy, as opposed to adopting the ideology as a means towards other ends. This motivation was represented more often in Study 1 than in Study 2, perhaps due to selection bias. People who radicalized due to this motivation tend to be - as one of the interviewees explained - more deeply and genuinely committed to the ideology and are therefore less likely to seek the help of a deradicalization programme; this could explain why almost all experts mentioned this type of radical, yet almost none of them report having come across such a case in their programme.

Additionally, there might be a source bias at work: On the one hand, because need for existential meaning is conceivably a more socially desirable motivation than need to belong or need for status (social isolation, loneliness, low self-esteem are all perceived as undesirable and pitiful qualities, whereas a need for existential meaning can be stylized into something profound and heroic), people might be more likely to claim this motivation for themselves in self-report than experts talking about people they worked with. On the other hand, this motive might also have been present in the people the experts worked with, but not as accessible to the experts, who tend to focus on more hands-on factors they can utilize in their work (such as job prospects, changing the social environment etc.).

In summary, the most common needs were connected by an overarching theme of finding one's identity and one's place in life: need to belong, personal uncertainty and need for status. At the intersection of personal uncertainty and need to belong was identity in the sense of "who I am is whom I'm with, whom I belong to", while at the intersection of personal uncertainty and need for status was identity as "who I am is who I'm seen as, what I'm admired for". In contrast, the needs for justice, sensation and romance are likely to play a merely supporting role; it is common for people to join radical groups because of other motives, but once they are a member, they are offered adventure, romance and/or the conviction that they are acting in the name of justice, 
and these factors add to the group's attractiveness. The different roles these motivational needs play in the process and the manifold possibilities of combining them are why the proposed typology was not fit to describe the data and any attempt to frame them within an alternative typology would likely prove equally restrictive; the needs are best examined on their own, as this allows the model to be more flexible.

Finally, it is notable that the meaningful differences lie between motivations, rather than ideologies (political or religious). The attractiveness of a particular group or ideology varies according to the psychological needs currently salient to a person. We found that oftentimes, when people are motivated by a need for identity and a need to belong, the ideology is basically interchangeable - the group selected is simply the first group to come along and offer a supply that meets the person's demands. Other groups pander to specific motivations - an example from Study 2 was the PKK, a radical pro-Kurdish group which exclusively appeals to members of the Kurdish people who are motivated by a need for justice and existential meaning. The one big difference between ideologies we found concerned the reintegration-process after disengagement: a difference in stigmatization. Former left-wing extremists face the least number of obstacles and social resentment when trying to return into the centre of society, followed by right-wing extremists, while former Islamist extremists frequently face grave problems (in Germany - this order is likely to vary interculturally).

\subsection{Limitations and strengths}

While a larger sample size is always desirable, this factor is not as problematic in qualitative studies. However, generalisability of our findings is limited due to sampling issues in Study 1. Firstly, the sample was almost exclusively female, with only one male out of five participants. This is unusual, considering radicalization and ideo- 
logically motivated crime are a predominantly male issue (see, for example, Statistisches Bundesamt 2018,28$).{ }^{1}$ The issue of gender differences in radicalization is an important one and systematic research on this topic is needed; our own capacities to discuss these are, however, limited due to the asymmetry in our data sets. While our data from Study 1 concern exclusively the early stages of radicalization and almost exclusively females, our experts from Study 2 work with clients who went through the final stages of radicalization and, in many cases, committed crimes in relation to this. Their knowledge is hence based on a more representative, i.e. mostly male, sample. Insofar as the patterns in our results overlapped between both studies despite this asymmetry in samples, this can be considered further proof of their robustness.

Secondly, neither the sampling nor the interviews were conducted with a focus on radicalization; we received data from a study on Muslims' religious development, conducted on a sample of self-identified devout Muslims and with a very open methodology, and had a sub-sample for our secondary analyses selected for us based on contact with radical groups. Both this sampling and the open, non-specific interview method likely resulted in us missing out on information that might have otherwise been gained from more tailored interviews. There was a second, related sampling issue in Study 1: Since all participants had disengaged during the early stages of radicalization, the generalizability of this study's results could be questioned. Arguably, people who disengage very early could be expected to be systematically different from those who disengage very late in the process. However, our results from Study 2, in which we

\footnotetext{
${ }^{1}$ Articles 129a to 130 Par. 4 of the German Penal Code are various ideologically motivated crimes; note that in the Criminal Prosecution Statistics referenced here, the rows marked with $i$ stand for the total number of crimes and the rows marked with $m$ for the number of crimes committed by males. The statistics show that all of these ideologically motivated crimes were committed by mostly men.
} 
collected second-hand data on people who had gone through the final stages of radicalization before disengaging, largely replicated the patterns found in Study 1 (except for some differences regarding need for status and need for existential meaning). Thus, we conclude that our different data sources actually speak to the robustness of the patterns we found.

At the same time, the methodology of Study 1, in particular in combination with the data from Study 2, has advantages. The very open format of the narrative interview gave participants room to set their own focus and highlight the factors that seemed most important to them in their own development. The combination of first-hand and second-hand data in both studies allowed us to offset potential biases in each data source (social desirability in the first and lack of insight into certain aspects in the second study, as explained above on the example of need for existential meaning and need for status) and to tackle the issue of motives for radicalization from different points of view. The fact that - apart from the slight difference in need for status and need for existential meaning - the distributions of the psychological needs were the same in both studies demonstrates that the motivational model we tested might indeed be valid across different perspectives on the radicalization process. The central motives that have been discussed by researchers and combined in the model we tested by Macdougall et al. accurately reflect what is central to people who have experienced radicalization first-hand and what experts experience in their work.

Finally, the issue of reliabilities limits our data's interpretability. As explained, the structure of our data and the way they were coded did not allow for the calculation of any of the conventional indices. The interviews were not subdivided before coding - the coders applied whichever code seemed fit to however long of a segment seemed to match the description; there was a minimum, but no maximum for the coding units, i.e. the coders created the coding units during the process. As a result, the only index 
of interrater agreement that could be established is the percentage overlap, which is a limited indicator of reliability.

That said, although most codes did not have very high overlap during the first round of coding in both studies (Study $1: M=55,00 \%$; Study $2: M=63,71 \%$ ) the coders reached $100 \%$ agreement on the majority of them during the discussion of the results. The overlap for the first round of coding also improved on average from Study 1 to Study 2, which is indicative of a learning curve. This demonstrates that the coding system was complex and extensive, which presented a burden on the coders' concentration, but overall reasonably clear and applicable. In particular, inter-coder overlap for the psychological needs was high in comparison to the other factors included in the complete coding scheme.

\subsection{Implications}

The key findings from our study for practitioners are that, firstly, underlying psychological motives affect individuals' sensitivity to different (de-)radicalizing factors - as demonstrated by the finding that different psychological needs make different radical groups and ideologies appealing to the individual - and, secondly, that, rather than try to find an ideal typology, it is useful to observe the psychological needs salient for a person and how they might change over time, as there are often multiple needs present and their saliency may change according to the extent to which they are being met. For example, if a person's need for status is very strong, a practitioner may help them to disengage from their radical group by employing measures that increase their self-esteem and perceived social value, such as career development measures, education, inclusion in volunteering activities etc.

Notably, we do not have the data to conduct an in-depth comparison of radicalization and deradicalization in this study, but we have observed that in general, 
the motives behind deradicalization will likely be connected to those behind radicalization. It is important to realize that when people enter the phase of deradicalization, they may enter a new place in life, in which the original motivations may be fulfilled in another manner. For example, when people were motivated to join a radical group due to sensation seeking motivation, they may want to find alternative ways to fulfil this need for sensation, for example by doing an exciting and physically challenging sport.

Our findings should also encourage policy makers and professionals to not think of political and religious radicalization as two entirely separate and fundamentally different phenomena and instead focus on the individual and their underlying psychological motives. Finally, keeping in mind the crucial role of need to belong in pre-existing literature and our study, policy measures which foster social inclusion of groups vulnerable to radicalization - such as initiatives fostering employment and facilitating the pursuit of education or policy communication which lessens the perceived intergroup gap - should be regarded in the context of preventive measures. In general, fostering initiatives which support at-risk youth by promoting social inclusion, self-esteem and self-efficacy is the most basic form of radicalization-prevention a state can undertake and can be expected to affect a large portion of those at risk for radicalization. 


\section{References}

Altier, Mary B., Christian N. Thoroughgood, and John G. Horgan. 2014. "Turning Away from Terrorism: Lessons from Psychology, Sociology, and Criminology." Journal of Peace Research 51 (5): 647-61. doi:10.1177/0022343314535946.

Bakker, Edwin, and Seran de Leede. 2015. "European Female Jihadists in Syria: Exploring an Under-Researched Topic." International Centre for Counter-Terrorism.

Barrelle, Kate. 2014. "Pro-Integration: Disengagement from and Life After Extrem -ism." Behavioral Sciences of Terrorism and Political Aggression 7 (2): 12942. doi:10.1080/19434472.2014.988165.

Baumeister, Roy F., Lauren E. Brewer, Dianne M. Tice, and Jean M. Twenge. 2007. "Thwarting the Need to Belong: Understanding the Interpersonal and Inner Effects of Social Exclusion." Social and Personality Psychology Compass 1 (1): 506-20. doi:10.1111/j.1751-9004.2007.00020.x.

Baumeister, Roy F., and Mark R. Leary. 1995. "The Need to Belong: Desire for Interpersonal Attachments as a Fundamental Human Motivation." Psychological Bulletin (117(3)): 497-529.

Bjørgo, Tore. 2011. "Dreams and Disillusionment: Engagement in and Disengagement from Militant Extremist Groups." Crime, Law and Social Change 55 (4): 277-85. doi:10.1007/s10611-011-9282-9.

Bock, Michael. 2017. "Radikalisierung. Ein Essay Mit Der Absicht Der Verfremdung." Neue Kriminalpolitik 29 (4): 450-68. doi:10.5771/0934-9200-2017-4-450.

Borum, Randy. 2003. "Understanding the Terrorist Mind-Set." FBI Law Enforcement Bulletin July (72): 7-10.

Braun, Virginia, and Victoria Clarke. 2006. "Using Thematic Analysis in Psychology." 
Qualitative Research in Psychology 3 (2): 77-101.

doi:10.1191/1478088706qp063oa.

Choudhury, Tufyal. 2007. "The Role of Muslim Identity Politics in Radicalisation: (a Study in Progress)." London, UK, Department for Communities and Local Government.

Cottee, Simon, and Keith Hayward. 2011. "Terrorist (E)Motives: The Existential At-tractions of Terrorism." Studies in Conflict \& Terrorism 34 (12): 963-86. doi:10.1080/1057610X.2011.621116.

Dechesne, Mark. 2011. "Deradicalization: Not Soft, but Strategic." Crime, Law and Social Change 55 (4): 287-92. doi:10.1007/s10611-011-9283-8.

Della Porta, Donatella, and Gary LaFree. 2012. "Guest Editorial: Processes of Radicalization and De-Radicalization." International Journal of Conflict and Violence 6 (1): 4-10. doi:10.4119/UNIBI/ijcv.266.

Demant, Froukje, Marieke Slootman, Frank Buijs, and Jean Tillie. 2008. "Decline and Disengagement: An Analysis of the Process of Deradicalization." Institute for Migration and Ethnic Studies. Amsterdam.

Doosje, Bertjan, Annemarie Loseman, and Kees Van den Bos. 2013. "Determinants of Radicalization of Islamic Youth in the Netherlands: Personal Uncertainty, Perceived Injustice, and Perceived Group Threat." Journal of Social Issues 69 (3): 586-604. doi:10.1111/josi.12030.

Doosje, Bertjan, Fathali M. Moghaddam, Arie W. Kruglanski, Arjan de Wolf, Liesbeth Mann, and Allard R. Feddes. 2016. "Terrorism, Radicalization and De-Radicalization." Current Opinion in Psychology 11:79-84. doi:10.1016/j.copsyc.2016.06.008.

Doosje, Bertjan, Kees Van den Bos, Annemarie Loseman, Allard R. Feddes, and 
Liesbeth Mann. 2012. ““My in-Group Is Superior! ”: Susceptibility for Radical Right-Wing Attitudes and Behaviors in Dutch Youth." Negotiation and Conflict Management Research 5 (3): 253-68. doi:10.1111/j.1750-4716.2012.00099.x. Dugas, Michelle, and Arie W. Kruglanski. 2014. "The Quest for Significance Model of Radicalization: Implications for the Management of Terrorist Detainees." Behavioral sciences \& the law 32 (3): 423-39. doi:10.1002/bsl.2122.

Feddes, Allard F., Lars Nickolson, and Bertjan Doosje. 2018. Trigger Factors in the Radicalisation Process: An Integrative Literature Review. Amsterdam. [Unpublished manuscript, available from authors]

Fuß, Susanne, and Ute Karbach. 2014. Grundlagen Der Transkription: Eine Praktische Einführung [Basics of transcription: A practical introduction]. 1. Ed.: Sozialwissenschaften. Leverkusen, Leverkusen: UTB; Budrich, Barbara.

Gellin, Märtha L. M. 2015. "Search for Romance or Holy War? A Discourse Analysis of Swedish Counter Radicalisation and Its Gendering of Females in Violent Jihadi Organisations." Dissertation, University of St. Andrews.

“German Criminal Prosecution Statistics for 2017 [Strafverfolgungsstatistik]." 2018. Fachserie 10, Reihe 3. Last modified September 14, 2019. Retrieved from: https://www.destatis.de/GPStatistik/servlets/MCRFileNodeServlet/DEHeft_derivate_00040937/2100300177004.pdf;jsessionid=15671C41A76DDDFA05DA7871E59BC581.

Gollwitzer, Mario, Tobias Rothmund, Andreas Pfeiffer, and Conrad Ensenbach. 2009. "Why and When Justice Sensitivity Leads to Pro- and Antisocial Behavior." Journal of Research in Personality 43 (6): 999-1005. doi:10.1016/j.jrp.2009.07.003.

Harris, K. J., E. Gringart, and D. Drake. 2017. “Leaving Ideological Groups Behind: A 
Model of Disengagement." Behavioral Sciences of Terrorism and Political Aggression, 1-19. doi:10.1080/19434472.2017.1299782.

Hogg, Michael A. 2014. "From Uncertainty to Extremism." Current Directions in Psychological Science 23 (5): 338-42. doi:10.1177/0963721414540168.

Hoyle, Carolyn, Alexandra Bradford, and Ross Frenett. 2015. “Becoming Mulan? Fe male Western Migrants to ISIS." Institute for Strategic Dialogue.

King, Michael, and Donald M. Taylor. 2011. "The Radicalization of Homegrown Jihadists: A Review of Theoretical Models and Social Psychological Evidence." Terrorism and Political Violence 23 (4): 602-22. doi:10.1080/09546553.2011.587064.

Kruglanski, Arie W., Xiaoyan Chen, Mark Dechesne, Shira Fishman, and Edward Orehek. 2009. "Fully Committed: Suicide Bombers' Motivation and the Quest for Personal Significance." Political Psychology 30 (3): 331-57. doi:10.1111/j.1467-9221.2009.00698.x.

Macdougall, Alex I., Jaap van der Veen, Allard R. Feddes, Lars Nickolson, and Bertjan Doosje. 2018. "Different Strokes for Different Folks: The Role of Psychological Needs and Other Risk Factors in Early Radicalisation." International Journal of Developmental Science 12 (1-2): 37-50. doi:10.3233/DEV-170232.

Reiter, Julia. 2018. "Finding One's Feather, Finding One's Flock: Need for Identity, Social Belonging, and Other Key Factors in the Process of (De-)Radicalization: An Exploratory Interview Study." Master Thesis, Georg-Elias-Müller Institut für Psychologie, Georg-August-Universität.

Schils, Nele, and Antoinette Verhage. 2017. "Understanding How and Why Young People Enter Radical or Violent Extremist Groups." International Journal of Conflict and Violence 11: 1-17. doi:10.4119/UNIBI/ijcv.473.

Schütze, Fritz. (1976). "Zur Hervorlockung Und Analyse Von Erzählungen Thema- 
tisch Relevanter Geschichten Im Rahmen Soziologischer Feldforschung. Dargestellt an einem Projekt zur Erforschung von kommunalen Machtstrukturen." In Kommunikative Sozialforschung. Alltagswissen und Alltagshandeln, Gemeindemachtforschung, Polizei, Politische Erwachsenenbildung., 159-260.

Tajfel, Henri, and John Turner. 1979 (reprinted 2004). "An Integrative Theory of Intergroup Conflict." In Organizational Identity: A Reader, edited by Mary J. Hatch and Majken Schultz, 56-65. New York: Oxford University Press.

Tajfel, Henri, and John C. Turner. 1986 (reprinted 2004). "The Social Identity Theory of Intergroup Behavior." In Political Psychology - Key Readings, edited by John T. Jost and Jim Sidanius, 276-93. New York: Psychology Press. https://content.taylorfrancis.com/books/download?dac=C2009-0-238069\&isbn=9780203505984\&doi=10.4324/9780203505984-16\&format=pdf.

Van den Bos, Kees. 2018. Why People Radicalize: How Unfairness Judgments Are Used to Fuel Radical Beliefs, Extremist Behaviors, and Terrorism. Oxford: Oxford University Press.

Veldhuis, Tinka. 2012. "Designing Rehabilitation and Reintegration Programmes for Violent Extremist Offenders: A Realist Approach." ICCT Research Papers. doi:10.19165/2012.1.02.

Venhaus, John M. 2010. "Why Youth Join Al-Qaeda." Special Report, United States Institute of Peace.

Webber, David, and Arie W. Kruglanski. 2018. "The Social Psychological Makings of a Terrorist." Current Opinion in Psychology 19:131-34. doi:10.1016/j.copsyc.2017.03.024.

Zhao, Xinshu, Jun S. Liu, and Ke Deng. 2016. "Assumptions Behind Intercoder Reliability Indices." Annals of the International Communication Association 36 (1): 419-80. doi:10.1080/23808985.2013.11679142. 
Table 1. Overview of participants in Study 1.

\begin{tabular}{|c|c|c|c|c|c|c|}
\hline Code & $\begin{array}{l}\text { Duration } \\
\text { of Inter- }\end{array}$ & Age & $\underline{\text { Sex }}$ & $\begin{array}{l}\text { Nationality/ } \\
\text { Ethnicity }\end{array}$ & $\begin{array}{l}\text { Educational } \\
\text { Background }\end{array}$ & $\begin{array}{l}\text { Relation } \\
\text { to Islam }\end{array}$ \\
\hline & view & & & & & \\
\hline 1.1 & $120 \min$ & 21 & $f$ & $\begin{array}{l}\text { German with Turk- } \\
\text { ish background }\end{array}$ & $\begin{array}{l}\text { B.A. in Islamic } \\
\text { Theology }\end{array}$ & $\begin{array}{l}\text { Native } \\
\text { Muslim }\end{array}$ \\
\hline 1.2 & $111 \mathrm{~min}$ & 21 & $f$ & German & $\begin{array}{l}\text { B.A. in Psychol- } \\
\text { ogy }\end{array}$ & $\begin{array}{l}\text { Christian } \\
\text { convert }\end{array}$ \\
\hline 1.3 & $136 \min$ & 33 & $f$ & German & $\begin{array}{l}\text { Unemployed, no } \\
\text { education beyond } \\
\text { high school }\end{array}$ & $\begin{array}{l}\text { Christian } \\
\text { convert }\end{array}$ \\
\hline 1.4 & $146 \min$ & 21 & $\mathrm{~m}$ & $\begin{array}{l}\text { German with Alge- } \\
\text { rian background }\end{array}$ & B.A. Social Work & $\begin{array}{l}\text { Native } \\
\text { Muslim }\end{array}$ \\
\hline 1.5 & $141 \mathrm{~min}$ & 24 & $f$ & German & B.A. Sociology & Convert \\
\hline
\end{tabular}


Table 2. Inter-Coder Agreement per Code, Calculated Before and After Discussion

\begin{tabular}{|c|c|c|c|}
\hline & & Pre & Post \\
\hline & Overlap $\% 1^{*}$ & Overlap \% & Overlap \\
\hline$\underline{\text { Code }}$ & & $\underline{2^{* *}}$ & $\underline{\%}$ \\
\hline Need to belong & 28,57 & 35,71 & 92,86 \\
\hline Emotional uncertainty & 41,67 & 41,67 & 91,67 \\
\hline Need for justice & $\mathrm{nV}$ & $\mathrm{nV}$ & $\mathrm{nV}$ \\
\hline Need for sensation & $\mathrm{nV}$ & $\mathrm{nV}$ & $\mathrm{nV}$ \\
\hline Need for romance & 50 & 50 & 100 \\
\hline Need for existential meaning & 0 & 66,67 & 100 \\
\hline Need for status & 80 & 80 & 100 \\
\hline
\end{tabular}

as 1 , each disagreement as 0 ) divided by total number of codes (sum total of codes used by both coders is used).

** After the first round of coding, coder B received additional explanations of "Need for existential meaning", which they had not understood completely or correctly. Coder B then had the opportunity to re-evaluate their coding before discussion of the interview with coder A. The first two columns represent those two coding rounds. "nV" stands for "no value" - this code did not appear anywhere and was correctly not coded by either of the coders. 
Table 3. Overview of Participants in Study 2, Including Information on Them, Their Programmes and Clients

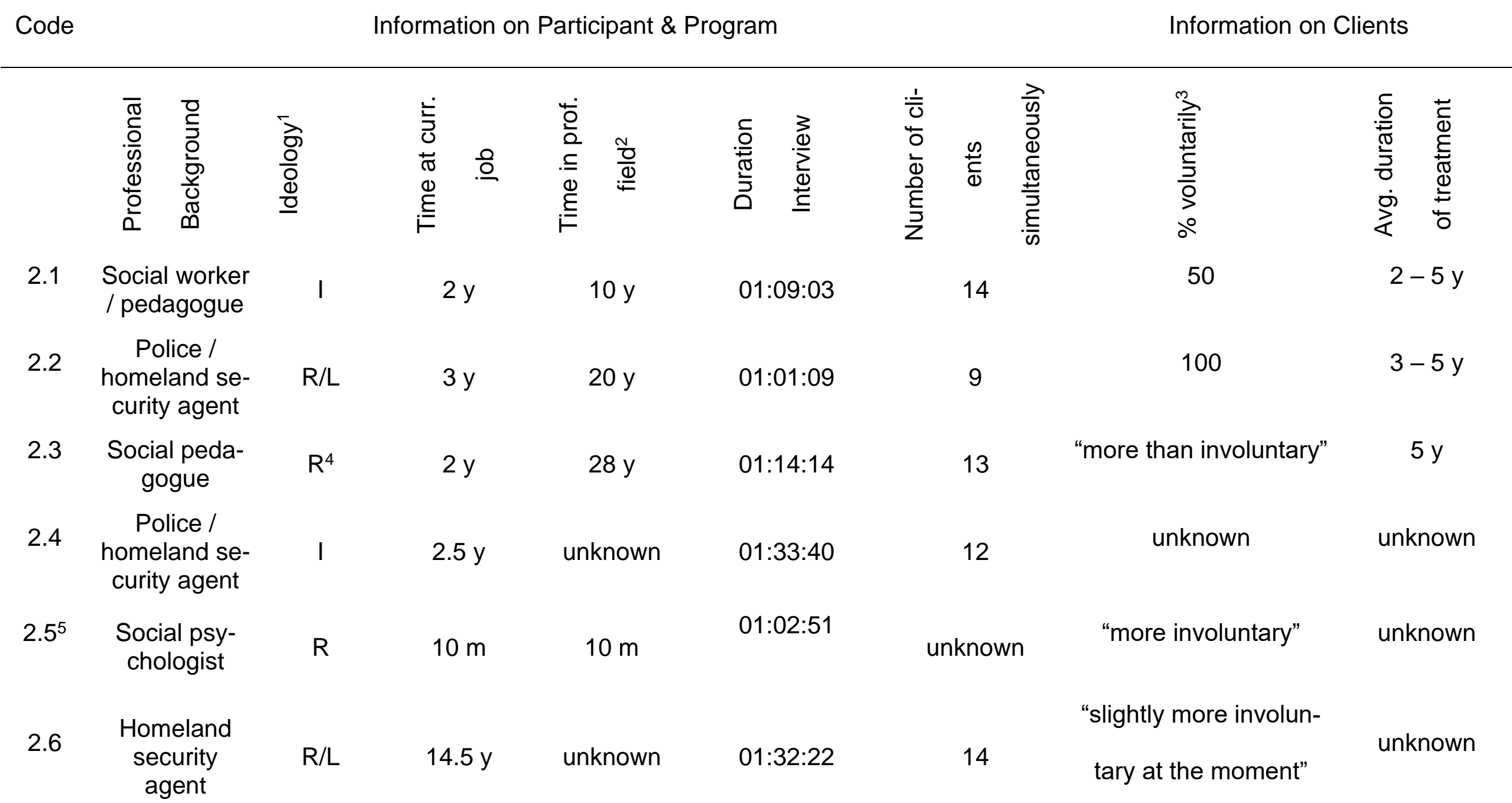




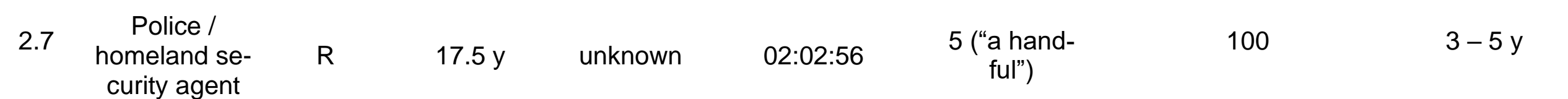

Note. ${ }^{1} \mathrm{I}=$ Islamism, R = Right-Wing Extremism, L = Left-Wing Extremism

${ }^{2}$ Work in roughly the same sector - e.g. interviewee 2.2 has been with his current deradicalization-programme for three years but has been a member of the police force for 20 years.

3 To some extent, it has been clarified unanimously by all of the interviewees, all participants of the programmes have to be there "voluntarily" since their approaches don't include the option of working with people against their will. The question of percentage of voluntary participants here refers to how many of the participants get in touch with the programme themselves, as opposed to being sent there by a judge, a parole officer etc.

${ }^{4}$ Not only responsible for right-wing extremism, but also for motorbike gangs, allowing for comparisons between radical and non-radical group-based crime.

5 Only non-state-run programme in the study. 
Table 4. Inter-Coder Agreement per Code, Calculated Before and After Discussion

\begin{tabular}{|c|c|c|}
\hline & $\underline{\text { Pre }}$ & Post \\
\hline$\underline{\text { Code }}$ & Overlap \%* & Overlap \% \\
\hline Need to belong & 35,71 & 86,67 \\
\hline Emotional uncertainty & 50 & 100 \\
\hline Need for justice & 60 & 100 \\
\hline Need for sensation & 100 & 100 \\
\hline Need for romance & 100 & 100 \\
\hline Need for existential meaning & 60 & 100 \\
\hline Need for status & 40 & 80 \\
\hline
\end{tabular}




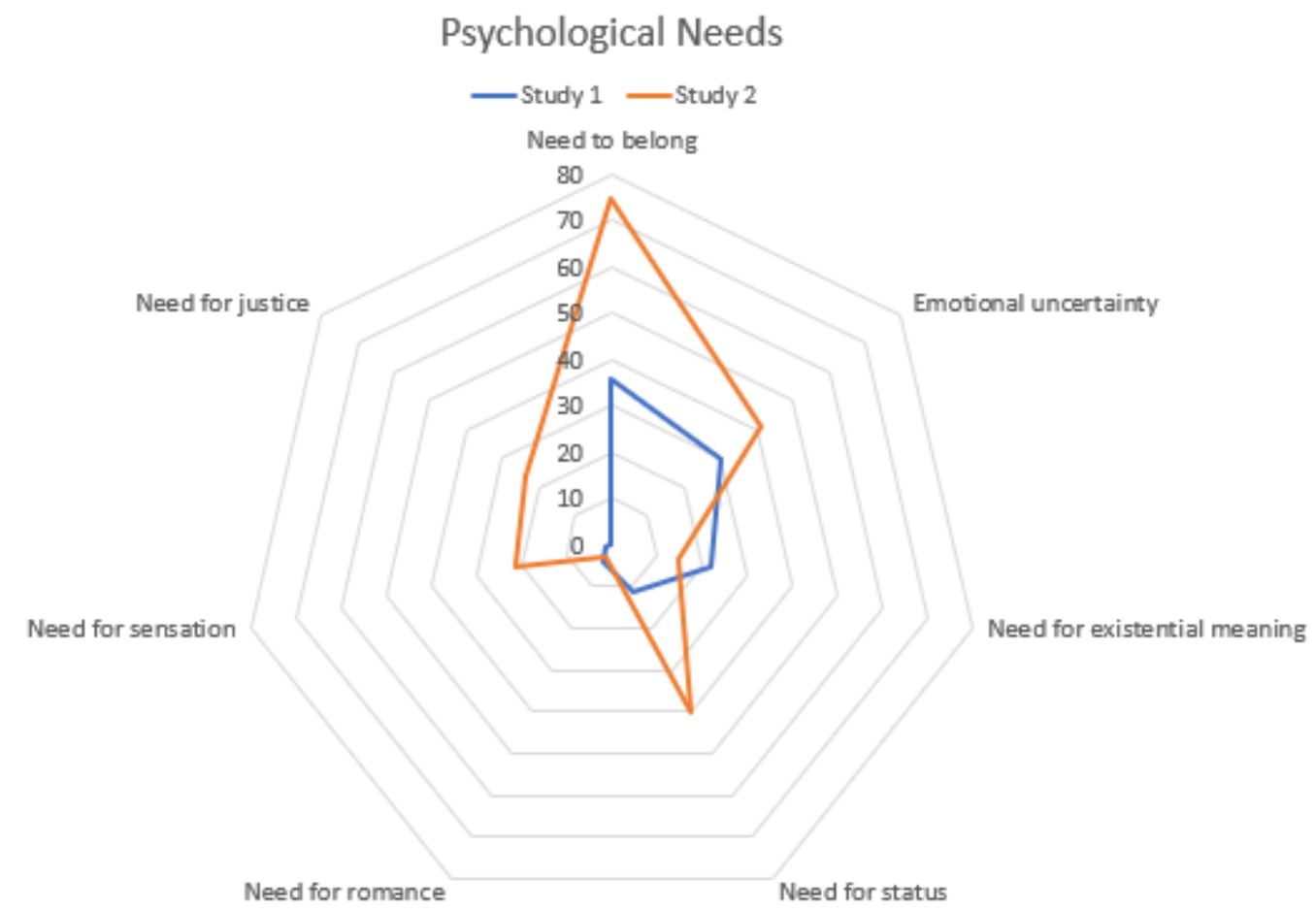

Figure 1. Frequency of the seven psychological needs in both studies. Note: The numbers displayed represent the absolute amount of times each need was coded across all interviews. 


\section{Appendices}

Appendix 1 (Supplementary Online Material)

All Codes Used in Study 1, Sorted Within Categories by Frequency of Usage and Including

Definitions and Examples

\begin{tabular}{|c|c|c|c|c|}
\hline Theme & $\underline{\text { Code }}$ & Definition & $\begin{array}{l}\text { Nr. of in- } \\
\text { stances }\end{array}$ & Example $^{2}$ \\
\hline Phases & $1 \mathrm{~V}$ & $\begin{array}{l}\text { Vulnerability phase: a } \\
\text { period during which } \\
\text { any number of risk fac- } \\
\text { tors are present, mak- } \\
\text { ing the individual sus- } \\
\text { ceptible to radical ideo- } \\
\text { logies (as well as other } \\
\text { harmful influences). }\end{array}$ & 0 & - \\
\hline & $2 \mathrm{E}$ & $\begin{array}{l}\text { Exploration phase: a } \\
\text { period during which the } \\
\text { individual is actively } \\
\text { seeking to engage with } \\
\text { and acquire } \\
\text { knowledge about a po- } \\
\text { tentially radical ideol- } \\
\text { ogy. }\end{array}$ & 23 & $\begin{array}{l}\text { 1.1: "For example, when I started to } \\
\text { become religious, I followed some } \\
\text { Muslim websites, so to speak, then } \\
\text { I followed some other websites and } \\
\text { eventually a lot of Muslim sites } \\
\text { which were posting about Islamic } \\
\text { topics and so on. And I don't re- } \\
\text { member how I got into the }\end{array}$ \\
\hline
\end{tabular}

\footnotetext{
${ }^{2}$ All interviews analysed here were conducted in German. Examples selected here were translated for publication by the author. (...) stands for parts omitted from the citation for brevity's sake, contents in [ ] are author's remarks or supplementations for context.
} 
WhatsApp-groups, but I suppose I somehow met some girls, the stuff I posted was the sort of thing through which one would meet other girls, for example in the comment section $(\ldots) "$

3M Membership phase: a 9 1.4: "(...) to me, when I kept seeing period starting with the them on the internet, they were like individual joining a radstars to me, like celebrities. So I reical group (physically ally met them in [city] and I said 'I or perhaps virtually) want to join you, please', immediand lasting for the entire duration of the individual's stay in the group. ately, the first time I saw them. They said 'Yes, please come by tomorrow', we talked about everything, how everything would go and so on and then I joined them."

4A Action phase: a period 0

during which the individual partakes in violent group activities or engages in criminal or generally violent activities because of their ideology and/or group membership. 


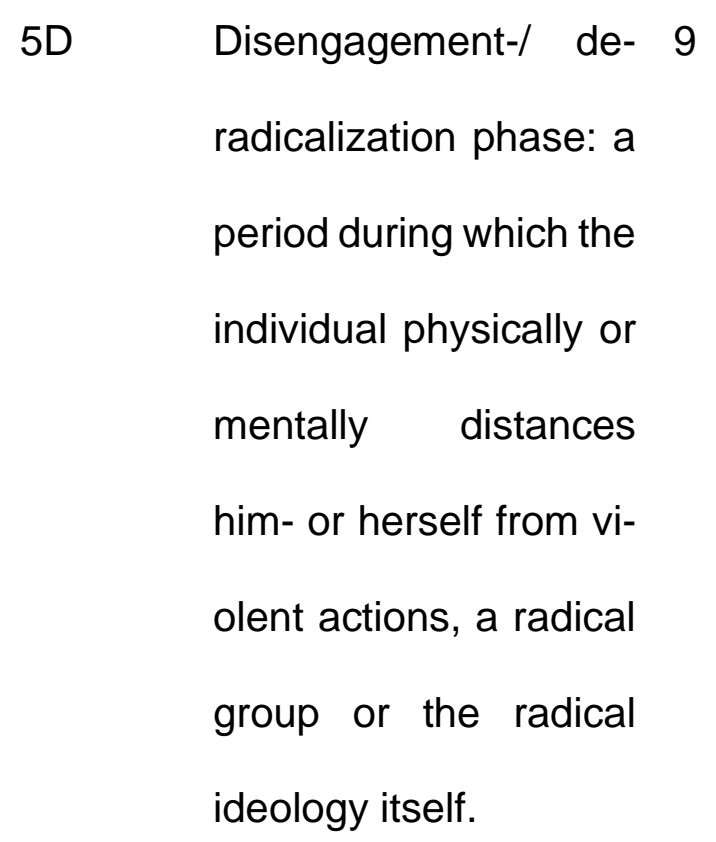

Micro- T_dom Domestic problems: 46

Level any grave problems

within the domestic sphere, examples include financial problems of the family, intense intrafamiliar conflict, problematic behaviour by family members, such as crime, drug abuse etc.

T_disc Discrimination, racism and general exclusion: any experiences of racially or non-racially
1.4: “(..) until it got very extreme due to this hatred for the Shiites and I got blocked [on a social media website] and then I told myself 'no, if you do this kind of thing again, you might be reported to the police or something', and since l've never caught the police's attention and hopefully never will, I told myself 'you better just stop this', and well."

1.2: “(...) my parents separated very early. They'd gotten married in secret because of my dad's parents, they are very narrow-minded. (...) so I basically grew up within the custody battle between them (...)"

1.1: "Once when I was 14, during gym class, my teacher said to me 'I heard you were getting married off against your will. Is that true?' And I 
motivated exclusion, such as bullying, verbal attacks aimed at perceived group membership etc. told him 'No, that's not true', and in that moment, when I said that, I thought 'how will I know if he believes me? Maybe he doesn't believe me.' And I felt so... disgusting, because I felt like my word had no value, like on these oppressed women, we feel so sorry for them and when they speak, they only say whatever they say because they're being forced to say it, that's how I felt."

T_persp Loss of perspectives in the academic or professional sphere: experiences of academic failure or lack of perspectives on the job market.

T_aut Negative experiences 17 with authorities: encounters with authorities, i.e. any official State representatives or employees (police,
1.4: "(...) in 2014 , I had to repeat my final year of high school, because I was always ... at the prison, visiting both of them [i.e. his parents], and I didn't yet know what was going on at the time."

1.4: "And then, on January $4^{\text {th }}$, the police came with seven policemen, they kicked in the door and chased me out of bed, they asked where my father was etc., [so I said] 'At the gym I guess', then I called there and 
administrative bodies

etc.), which were per-

ceived negatively. he came home and promised me, he would come back home tomorrow, and they took him with them.

(...) And then I asked the policemen 'Can I please call my mother, this is all too much for me right now?' and they said 'No, you don't need to, and please talk in German when you talk to your father' (...) and then I found out that my mother had been arrested in [city] when she was transporting [my father's drugs]. And that was why she was not home yet."

T_death Confrontations with 9 1.3: "My mother suffered from borredeath: deaths of family members, friends or any other people of significance to the individual; confrontations with own mortality.

T_det Detention: Any amount 0

of time the individual has spent in custody or in prison. liosis and cancer and died when I was 14 , so I didn't grow up completely normally, that doesn't happen to everyone." 
Meso- T_socb Cutting social bonds: 18

Level

any instances in which the individual initiates

the termination of a so-

cial relationship, usually in the course of and due to their increased commitment to an ideology.
1.4: "[My social circle] became smaller. That was the change. I made very few new friends, but I cut ties with many, many more of them. Like I said, it was never because of who they were as a person, but more because they had different hobbies or interests from which I was seeking to distance myself, because they weren't relevant to me. And for example, I used to love shisha, smoking shisha, and we used to have these evenings where we smoked shisha and played on the Playstation, FIFA, boys' evenings, and I turned my back on that, because I turned my back on the shisha, because I didn't want to do that anymore, and I knew that they were always drinking alcohol, and I didn't want to take part in that anymore."

T_mrg Marriage (to a radical 11 person as a radicalising factor or to a nonradical person as a
1.1: “(...) and now we've been married for one and a half years and I'm very happy and very satisfied, and I am glad that our marriage is going 
protective/deradicaliz-

ing factor).

T_prpg Confrontations with 9

propaganda: encoun-

ters with materials in-

tended to propagate a

radical ideology, e.g.

public sermons, pam-

phlets, books, web-

sites, propaganda vid-

eos on YouTube etc. well. l'd rather be tested by God in all other areas and have difficulties anywhere else but in my marriage. So I am really very happy and super satisfied."

1.1: "And the standard run of the mill Muslim can't differentiate there, because they all sound like they're right, they all have good arguments, and you think, okay, who's right here, and everyone just picks someone, I know many people, who...got into this via the internet. On the internet, there's just...there's everything, from $A$ to $Z$, and you never know, okay which one is the classic, normal [version] and there are many sects there and many can't differentiate between these, they just think, yes this must be right, this sounds logical. And then I also got into Salafism slightly (...)."

T_grp Joining a radical group: 7 becoming a member of

1.1: "And...mostly through the WhatsApp-groups and Instagram, a physical or virtual 
radical group (includ-

ing Social Media).

T_meet Meeting a radical per- 4 son

T_cmp Participation in a train- 1 ing camp/course: participation in one or several events organized by a radical group and specifically designed to impart their ideology or prepare participants for radical actions.

Macro- T_igatk Perceived attacks on 11 Level the in-group: the individual perceives that
Social Media, because these people are mostly active on Social Media, they don't go outside or anything, well they do go outside, but they don't go to the mosque. There are hardly any Salafists at the mosque." 1.1: "There are some Salafimosques where the Salafists meet. And that's how I got into this. But it only went on for two, three months. There are people who were there for two, three years."

1.4: "We always had these seminars... where I thought all the people, or most of the people who were there...weren't quite right in the head, but that's a different matter."

1.3: "Where's the problem if a pupil goes to pray for five minutes during lunch break? The others stand in the corner and smoke. Where's the 
an action by an individ-

ual, a group or even a

government is an at-

tack on not just one or

several people, but on

the individual's in-

group as a whole. The

individual therefore

feels victimized even

though the action in

question may not be

affecting him or her di-

rectly.

T_plcy Governmental policy 6

aimed at radicalization

or at the in-group: the

individual reacts ad-

versely to governmen-

tal policies aimed at

the prevention of radi-

calization or the facili-

tation of deradicaliza-

tion (e.g. state-run exit

programmes) or at the problem? There's no need for a separate praying room, no one's asking for that. But why can't they just go stand in a corner and pray? There's a big fuss around this, you talk about religious freedom, but we can't pray in school anymore, what do you want? That only leads to hatred."

1.3: [Talking about a new law prohibiting women in Islamic face veils, burqas, from driving a car]: "It's nonsense, it does not serve the purpose of the law. Because it's not like there are reports in the media, millions of women wearing face veils are not paying their fines because they're not recognizable [in the pictures taken by traffic cameras]. That's not the case. There's a $60 €$ fine for that now. And I don't know that there are 
in-group (e.g. laws affecting a particular religious group).

T_cfact Calls for action: a radi- 1 cal group calling its members to action and others to join them, e.g. the IS announcing its foundation in 2014.

Risk- R_igid Ingroup Identification: 17 Factors the degree of in-group identification determines to what extent an individual feels belonging to his or her ingroup is central to his or her identity. any media reports during carnival, all the people in carnival-masks are not identifiable, so they go unpunished for driving over the speed limit. This law was only put in place because banning burqas completely in Germany would not be legally possible, so they ban them at the wheel instead."

1.1: “(...) that was also in 2014 , that was also the year the IS was announced $(\ldots) "$

1.1: “(...) if there's a Muslim in a class and then a topic comes up [connected to Islam], that person is always the contact person, always the expert for Islam, even though sometimes that's really...my sister is 12 and she is being treated just like that in her class, even though she doesn't have a clue." 
R_soc Harmful social environ- 10

ment: the harmful ab-

sence or presence of

social relationships;

the former might be a non-existing or bad relationship to attachment figures or other significant people in the individual's social environment, the latter might be the presence of social relationships with people who engage in and encourage criminal activities, drug abuse and other similar harmful behaviour.

\section{R_iganx Intergroup-Anxiety:} Feelings of anxiety related to perceived intergroup conflicts and the consequences
1.4: “I had many Russians in my school, Albanians too, and I was hanging out only with them, but they weren't good people, or good children at that time, they were the kind to screw things up, to throw stones throw windows and so on. They were all in contact with Child Protective Services, and so they pulled me in with them, and let me put it this way, if they already were this bad back then, and I'm speaking from experience based on cases I'm in charge of now, and nothing was done about it, it must get worse, and eventually, they'll be criminals. And had I grown up there and had no one helped us, then we would have become criminals as well."

1.1: "And in the very beginning, I was scared, even though I have many Christian friends as well, who are also very religious, and I get along with them very well, and even though I liked to meet with them, I 
these conflicts might

have for the individual.

$R$ _men Mental health issues: 8 reported diagnoses or symptoms strongly suggestive of diagnoses.

R_pinj Perceived injustice: 5 the perception that a group, most likely the individual's in-group, is being treated unfairly.

R_depr Perceived relative dep- 4 rivation (individual or collective): the perception that the individual or the individual's in- was still afraid to do something with non-Muslims. I was just scared of being exposed to these prejudices again."

1.3: "(...) I went to a boarding school in Denmark in 2001, I was feeling lovesick and somehow I couldn't cope with school, and so, stupidly, I attempted suicide, and then I came back to Germany, to a psychiatry...a special depression ward...I learned a whole lot about depression, which didn't really help. I don't think all these psychiatric wards are really any help."

1.4: "I didn't use to think like this, I used to say 'Terrorism is caused by the West, everything is always the West's fault'.

1.4: "The Muslims here in Germany are given many opportunities, but not this one, not when it comes to 
group are somehow at

a disadvantage com-

pared to an outgroup.

R_pt Perceived threat (sym- 3

bolic or realistic): the

perception that there is

a threat to symbols representative of the in-group or to the ingroup in economic or physical terms. having a really honest dialogue, and that is the problem."

1.1: [talking about her mother]: "She also didn't want me to wear the Khimar, because she was scared something would happen to me. She said 'I'm scared that someone will attack you' or something like that, because we know a woman who wears a normal headscarf, she comes from [city], and for example, when she was at the train station, someone hit her on the head and so on, even though she wears trousers and is dressed normally, she doesn't even look very shocking in the way she dresses, and my mother was very scared (...)"

Psy- nbel Need to belong: a de- 38 cholog- sire for social belonging, for group membership.
1.1: "I also had real identity issues, am I Turkish, am I German, am I Muslim, is that an identity and so on, so the standard problems." 
va-

tional

Factors

emunc Emotional uncertainty:
feelings of uncertainty
about own identity, cir-
cumstances, life in
general etc. - resulting
in a desire for uncer-
tainty avoidance.

nex- $\quad$ Need for existential 22

mean meaning: a desire for

definitive answers to

life's existential questions.
1.2: "And I quite liked it at the protectory, because I had rules, my mother never used to get up with me in the morning, because she just couldn't do it, she was up all night, and that means I always did all my stuff alone, I prepared breakfast alone and dressed myself, I washed myself, always, very, very early on. And [at the protectory] it was like this, you had to get up, then there was food, then there was time to wash oneself, and I liked that."

1.3: "I think it had to do with the eternal search for the meaning of life, at some point you think about that. In school we once had an exercise, 'What is the meaning of life', my answer was 'to find the meaning of life and live accordingly', which I then went on to do." 
nstat Need for status: a de- 11

sire for high personal

status, i.e. a desire to

be acknowledged and

appreciated as valua-

ble, important; a desire

to be looked up to.
1.1: "(...) maybe as a Muslim one has a certain inferiority complex, one's always being oppressed. There are wars in all Muslim countries and, I don't know, one is being discriminated against and that leads to an inferiority complex and one tries to hold onto something, and then one slides into this and everything falls into place."

1.4: "I think this will sound rather paradoxical, but I believe that was part of the appeal for me, because I knew that if I learn more about the religion, I might also be more attractive to Muslim girls (...)"

than that of long-term

connection and social

belonging.

nsens Need for sensation: a 1 desire for adventure, for risk-taking and excitement.
1.1: [On girls wanting to wear a niqab]: "And that's how that seems to me, like someone who is very excited about something and wants to try it, and many said to me 'I want to know how people will look at me', 
and I even did that too, in the very beginning, I wore a niqab outside, just to see what that's like, just to see how people look at me. And I know from my own personal experience that this just happens for attention, just for testing whether it's true that people look at you a certain way."

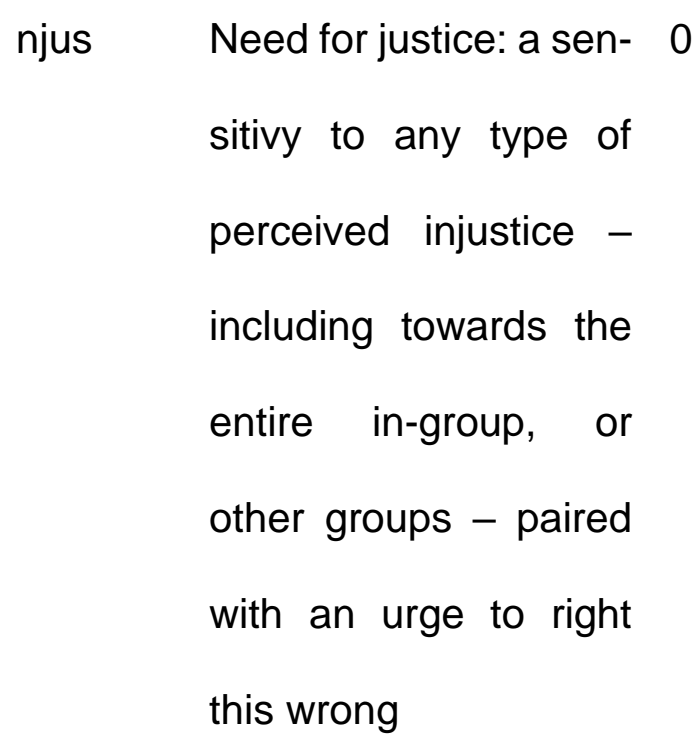

Protec- soc_pos Positive social influ- 56 tive ences: existing posiFactors tive relationships with attachment figures (e.g. parents), partners, other people in the individual's social
1.1: "To my mother, I could always talk on an emotional basis, my dad is kind of quiet, so we didn't talk to him like that very often. But, for example, I could always ask him any question. And then I thought, I was really lucky to have been brought up 
environment,

or

changes towards a

positive development

(e.g. terminating harm-

ful relationships, devel-

oping positive new re-

lationships).

critdiff Critical / differentiating

thinking: questioning

information, consulting

multiple sources, think-

ing for oneself and

reaching own conclu-

sions as opposed to

simply believing what

one is being told, rec-

ognizing differences

between situations, cir-

cumstances, people

etc.

acc

Experiences of ac- 28 like this and to have had parents like

this $(\ldots) "$

1.1: "And there were some really terrifying videos as well...and I thought, something's wrong here, this can't be right, because the way they argue makes you think okay, that sounds logical, but I thought to myself, something can't be right, because... if this really were Islam, and my parents are so religious, why would they not be doing this, they'd be the first ones to go there [to Syria to join ISIS], something's wrong here, why hasn't it always been like this, why aren't all Muslims like this, that's what I don't understand. That didn't make sense to me. (...)"

1.3: [On going out in a headscarf for ceptance: counterpart 
to experiences of dis-

crimination and exclusion, positive experiences of being accepted for who one is.

\begin{tabular}{|c|c|}
\hline perst & Perspective taking: \\
\hline & viewing a situation or \\
\hline & concept from alterna- \\
\hline & tive points of view, \\
\hline & comprehending \\
\hline & other individual's be- \\
\hline & haviour and thoughts. \\
\hline
\end{tabular}

dem/leg Positive attitudes to- 11 wards democracy and/or the legal order in general: counterpart to perceiving the State neither at the kindergarten, nor at the grocery store, nor anywhere else did anyone say anything...no one looked at me funny, as if I was looking completely normal, and I got very annoyed with myself, why didn't you go out like this sooner."

1.3: "No Muslim has ever demanded 'Your Christmas Market should be called Winter Market now', we don't care about that. (...) And I understand the Germans, I understand them $100 \%$ when they say 'Why does everything's name have to be changed now because of you? Why do we now have Day of Lights [instead of St. Martin's Day] and Winter-Fest [instead of Christmas]?' and we don't want that. They can call it what they want."

1.1: "Islamically speaking, we have a contract, so to speak, we are bound by the laws and we have to adhere to these laws, this contract. That is, from an Islamic point of 
and its authorities as il-

legitimate; a general

belief that democracy

is legitimate and posi-

tive, a trust in and reli-

ance upon the legal or-

der.

T_disil Disillusionment: a feel- 5

ing of disappointment

and dissatisfaction,

based on the realiza-

tion that something,

e.g. the radical group,

its members, leaders

and/or ideology, is not

what the individual

originally imagined it to

be.

Ambiv- comm Commitment: commit- 6

alent

ment to a cause, an

Factors ideology, a system of

values or a group, the view, according to some scholars, even a duty, and according to most it is at least a principle by which we should be guided. And being against them [the laws] is not allowed anyway."

1.3: [about Pierre Vogel, a famous German convert and preacher]: "What I can criticise are his disciples, in inverted commas, they are why, for example, I don't follow the Facebook page anymore. The things they, I think he could [try to] reprimand them occasionally, because of the way they insult and attack each other, and non-Muslims even more so. That is really beneath contempt, I think."

1.4: [About a radical group he temporarily was in contact with]: "Like I said, because they helped me. I was always grateful to them and I will always be grateful, no matter what 
latter close to the concept of organizational commitment.

resp Responsibility: responsibility for tasks (volunteering, jobs including responsibility for meaningful tasks, responsibility for caring for other people etc.); a sense of responsibility for choices made.

react Reactance: a motiva- 16 tional, adverse reaction to anything (people, offers, ideas etc.) that appears to be limiting the individual's freedom of choice or range of alternatives.

vio Experiences of vio- 6 lence: instances where the individual is either they might do now, I will always be grateful for what they did."

1.2 [about her younger sister]: "I only got to know her as a baby and for me, she always was like my own child, and I took care of her a lot, I always went outside with her and put her to bed and so on, I was really like a - well, I was ten years older."

1.1: "It's become something of a cult, my husband also says 'back in the day, you'd be a punk, today you're a Salafist', you want to attract attention, you want to be against the system (...)"

1.2: [About her mother's new boyfriend at the time]: "He locked me in the cellar and threatened me, he said things like 'If you don't shut 
the victim, witness or

perpetrator of violence. your mouth, then -', it was really sick. And my mother never believed

me $(\ldots) "$ 


\section{Appendix 2}

Complete List of Guiding Questions (first in English and then in German) Entry

- General information about the profession (How long have you been working in this field? What is your background - e.g. social work, psychology, ...? Have you always worked with the same group, i.e. right-wing extremists or Islamists, or have there been changes?)

- Everyday working life (How do clients typically come to you? Voluntarily, on referral, from the penal system,...? Typically members of a firm radical group or rather loose contacts to the scene? How many clients do you typically look after in parallel? How long do you usually work with one client? To what extent do you involve the client's social environment? etc.)

(1) Radicalisation

- Phases of radicalization: We understand "radical" as "ready to accept violence as a legitimate means of achieving political or social goals" and radicalization as the process leading to it. How do your clients report on this process? Have you been able to observe certain phases or stages that appear again and again?

- General risk factors: This refers to prolonged circumstances, conditions of the person or environment that increase the person's vulnerability and make him or her susceptible to radical ideologies or groups. What do clients typically report about the beginning of their radicalization process? What risk factors have you often observed?

- Trigger factors: This refers to concrete events that trigger or strongly accelerate a change in the radicalization process; for example: death in the family that leads to the person becoming more involved with religion and ending up in an Islamist group. Do you observe such trigger factors in your clients? Can you give examples? 
- Typology of different motivations: The scientific literature discusses the idea that people can be divided into types on the basis of different psychological needs. These needs are seen as a constant that motivates people's actions in the long run. The idea is that people who cannot meet these needs by other means feel attracted to radical ideologies or groups in this situation. It is also assumed that different types are attracted to different groups and respond to different triggers.

Do you see your clients trying to meet such needs? What needs have you often observed? How do you rate the idea of a typology, as described above, based on your experience? Could you form types yourself?

(2) Deradicalization

- Phases of deradicalization: How do you perceive the process of deradicalization? Can you describe the typical process, are there certain phases?

- Protective factors: Similar to the general risk factors, can you name protective factors whose development precedes and accompanies deradicalization? How does radicalisation end? Which factors play a role (especially in your work with clients)?

- Trigger factors: Do you observe trigger factors in your clients at the beginning or in the course of the deradicalization process? Can you give examples?

- Typology of different motivations: Analogous to above - do you observe different types of people who have deradicalized themselves? Can you give examples of motivations that drive deradicalization or needs that clients wanted to meet in the course of deradicalization?

(3) Further remarks: Would you like to add anything else? Did something not happen that you think is important? 
In German (original language)

Einstieg

- Allgemeines zum Beruf (Wie lang sind Sie bereits in diesem Bereich tätig? Was ist Ihr Hintergrund - z.B. Sozialarbeit, Psychologie, ...? Haben Sie immer mit der selben Gruppe, d.h. Rechtsextremen bzw. Islamisten, gearbeitet, oder gab es Wechsel?)

- Arbeitsalltag (Wie kommen die Klienten typischerweise zu Ihnen? Freiwillig, auf Verweisung hin, aus dem Strafvollzug,...? Typischerweise Mitglieder einer festen radikalen Gruppe oder eher lose Kontakte zur Szene? Wie viele Klienten betreuen Sie typischerweise parallel? Wie lang arbeiten Sie üblicherweise mit einem Klienten? Inwieweit beziehen Sie das soziale Umfeld des Klienten mit ein? etc.)

(1) Radikalisierung

- Phasen der Radikalisierung: Wir verstehen „radikal“ als „bereit, Gewalt als legitimes Mittel zur Umsetzung politischer oder gesellschaftlicher Ziele zu akzeptieren“ und Radikalisierung als den Prozess, der dazu führt. Wie berichten Ihre Klienten vom Verlauf dieses Prozesses? Konnten Sie bestimmte Phasen oder Stufen beobachten, die sich immer wieder zeigen?

- Generelle Risikofaktoren: Damit gemeint sind länger anhaltende Umstände, Zustände der Person oder des Umfelds, die die Vulnerabilität der Person erhöhen und sie für radikale Ideologien oder Gruppen empfänglich machen. Was berichten die Klienten typischerweise vom Anfang ihres Radikalisierungsprozesses? Welche Risikofaktoren konnten Sie häufig beobachten?

- Trigger-Faktoren: Damit gemeint sind konkrete Ereignisse, die eine Veränderung im Radikalisierungsprozess auslösen oder stark beschleunigen; Beispiel: Todesfall in der Familie, der dazu führt, dass Person sich verstärkt mit Religion 
beschäftigt und so schließlich in einer islamistischen Gruppe landet. Beobachten Sie solche Trigger-Faktoren bei Ihren Klienten? Können Sie Beispiele nennen?

- Typologie verschiedener Motivationen: In der wissenschaftlichen Literatur wird die Idee diskutiert, dass man Personen auf Grundlage verschiedener psychologischer Bedürfnisse in Typen unterteilen kann. Diese Bedürfnisse werden als Konstante gesehen, die langfristig die Handlungen der Personen motiviert. Die Idee ist, dass Personen, denen die Erfüllung dieser Bedürfnisse auf anderem Wege nicht möglich ist, sich in dieser Situation zu radikalen Ideologien oder Gruppen hingezogen fühlen. Zudem wird vermutet, dass die verschiedenen Typen sich zu unterschiedlichen Gruppen hingezogen fühlen und auf unterschiedliche Trigger reagieren. Beobachten Sie bei Ihren Klienten, dass sie versuchen, solche Bedürfnisse zu erfüllen? Welche Bedürfnisse haben Sie häufig beobachtet? Wie schätzen Sie die Idee einer Typologie, wie oben beschrieben, auf Grundlage Ihrer Erfahrungen ein? Könnten Sie selbst Typen bilden?

(2) Deradikalisierung

- Phasen der Deradikalisierung: Wie nehmen Sie den Prozess der Deradikalisierung wahr? Können Sie den typischen Verlauf beschreiben, gibt es bestimmte Phasen?

- Protektive Faktoren: Können Sie, analog zu den generellen Risikofaktoren, protektive Faktoren nennen, deren Entstehung der Deradikalisierung unmittelbar vorausgeht und sie begleitet? Wie endet Radikalisierung? Welche Faktoren spielen (insb. auch in Ihrer Arbeit mit den Klienten) eine Rolle? 
- Trigger-Faktoren: Beobachten Sie Trigger-Faktoren bei Ihren Klienten am Anfang oder im Laufe des Deradikalisierungsprozesses? Können Sie Beispiele nennen?

- Typologie verschiedener Motivationen: Analog zu oben - beobachten Sie verschiedene Typen von Personen, die sich deradikalisiert haben? Können Sie Beispiele für Motivationen nennen, die den Antrieb zur Deradikalisierung darstellen bzw. für Bedürfnisse, die Klienten im Zuge der Deradikalisierung erfüllen wollten?

(3) Weitere Anmerkungen: Möchten Sie noch etwas hinzufügen? Kam etwas nicht vor, das Sie für wichtig halten? 